\title{
Encryptomics: how Aristotle's causality system can be applied to new molecule discovery
}

\author{
Carlos Bloch Junior \\ From 5th Congress of the Brazilian Biotechnology Society (SBBIOTEC) \\ Florianópolis, Brazil. 10-14 November 2013
}

Aristotle (384 BC-322BC), the Greek philosopher formulated the concept of the Four Causes (material, formal, final and efficient causes), which in his view could explain how everything came about in the universe but its beginnings, called by him as the First Cause or the Uncaused Cause. Presently, modern Physics have a more elaborated view of the same principle considering that four discrete forces govern the interactions of matter in the known universe: gravity, electromagnetism, weak and strong nuclear force. As for the origins of the universe, we haven't made much conceptual progress since the Stageirian's work centuries ago.

Inspired by the Aristotelian Causality perceptiveness, its applications to chemical and biological systems, a novel screening strategy was conceived to find new biologically active molecules encrypted inside "parent macromolecules". The method [1] relays on in silico descriptors of a given activity (antimicrobial, opioid, inhibitors of enzyme activities), solid-phase peptide synthesis, mass spectrometry and NMR structural analysis, in vitro and in vivo assays [2].

Published: 1 October 2014

\section{References}

1. Brand GD, Magalhães MT, Tinoco ML, Aragão FJ, Nicoli J, Kelly SM, Cooper A, Bloch C Jr: Probing Protein Sequences as Sources for Encrypted Antimicrobial Peptides. PLoSOne 2012, 7(9):e45848.

2. de Magalhães MT, Barbosa EA, Prates MV, Verly RM, Munhoz VH, de Araújo IE, Bloch C Jr: Conformational and Functional Effects Induced by D- and L-Amino Acid Epimerization on a Single Gene Encoded Peptide from the Skin Secretion of Hypsiboas punctatus. PLoSOne 2013, 8(4): e59255.

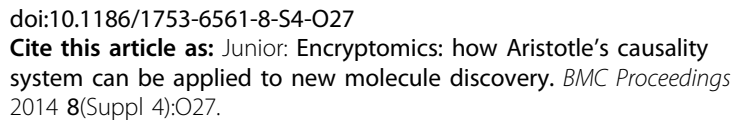

Submit your next manuscript to BioMed Central and take full advantage of:

- Convenient online submission

- Thorough peer review

- No space constraints or color figure charges

- Immediate publication on acceptance

- Inclusion in PubMed, CAS, Scopus and Google Scholar

- Research which is freely available for redistribution

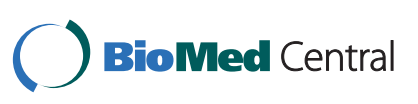

